\title{
Identification of Crop Groundwater and Surface Water Consumption Using Blue and Green Virtual Water Contents at a Subwatershed Scale
}

\author{
Geneva Starr • Jana Levison
}

Received: 19 May 2014 / Accepted: 6 October 2014 / Published online: 22 October 2014

(C) Springer International Publishing Switzerland 2014

\begin{abstract}
Large irrigation water withdraws are required where increasing development demands agricultural expansion. In many jurisdictions there is little documentation of agricultural water use, especially groundwater abstraction. Although primarily employed at a national scale, the concept of virtual water is used to calculate regional water-use. The main objective is to analyze watershed-scale crop-specific water consumption to identify local stresses and affected water systems. The $398 \mathrm{~km}^{2}$ quaternary watershed of Whitemans Creek in Ontario, Canada, is evaluated using an approach that can be applied to other locations using often-available data. Virtual water (VW) of major field crops is calculated for 1983, 2011 and 2012, using methods outlined in the FAO and Drainage Paper No. 56. The blue and green VW components are identified. Blue water is specified as ground or surface water, and green water as available soil water. Water consumption results are compared with the regional water budget. For 2011, green and blue VW requirements were 3,540 and $157 \mathrm{~L} / \mathrm{s}$, respectively. The blue water, over $80 \%$ sourced from groundwater, was comparable to the $151 \mathrm{~L} / \mathrm{s}$ agricultural water consumption estimate from the local water budget using general extraction coefficients. With agriculture in the subwatershed using $95 \%$ of the daily permitted blue water takings, identifying high water consumers and their withdrawal sources is important for land-use and water conservation planning. The VW calculations, using real climate data and crop inventory, provide field-scale information that can be applied as alternatives to general crop extraction coefficients.
\end{abstract}

Keywords Virtual water Green and blue water - Agriculture - Water consumption - Watershed Groundwater Water budget

G. Starr $\cdot$ J. Levison $(\bowtie)$

Water Resources Engineering, School of Engineering, University of Guelph, Thornbrough Building, N1G

2W1 Guelph, ON, Canada

e-mail: jlevison@uoguelph.ca

G. Starr

e-mail: gstarr@mail.uoguelph.ca 


\section{Introduction}

As the largest water consumer world-wide, the agriculture sector has become a primary issue for water resources management (Allan 2011). In regions where increasing development and population growth is demanding expansion of agriculture, large water withdrawals are required especially in arid and semi-arid locations. Irrigation is agro-economically beneficial by increasing soil productivity, extending growing seasons and enabling choice in crop types (Merrett 2002). However, in many locations, there is little documentation of actual agricultural water use, with the highest unknowns for groundwater abstraction (Zoumides et al. 2013). This is often attributed to no requirement for farmers to record actual water withdrawals, like in southern Ontario, Canada (AquaResource 2009a). Furthermore, although most water management decisions have been related to surface water takings, unsustainable groundwater depletion is increasing globally (Gleeson et al. 2012). In terms of agricultural use, groundwater is often preferred over surface sources for its higher reliability, presence on demand, and on-site extraction (Shah et al. 2003). To better understand how to increase water efficiency of farming, new methods for quantifying water consumption of crops and livestock have been emerging. One method includes calculating the virtual water content (VWC) of agricultural products at a regional scale.

The concept of virtual water was first explored by Tony Allan, and labeled in a 1992 workshop (Allan 2011). Referring to the water embedded in products being transferred through trade, it is an economic tool to be used to solve water scarcity (Allan 1996, 1997, 1998). This was demonstrated in the Middle East where, although it was one of the first locations to experience a water shortage, its economy remained stable by importing waterintensive cereals so that the water-deficit went unnoticed (Allan 1996). The use of virtual water trade to prevent visible water shortage has since been studied in other countries including Egypt, the South African Development Countries, and India (Earle and Turton 2003; Singh et al. 2004; Wichelns 2001). For the global water balance, water-rich countries should theoretically be net-exporters of virtual water, where water-rich refers to extensive renewable fresh-water resources or arable land with a temperate to humid climate (Allan 2011; Kumar and Singh 2005). According to Hoekstra and Hung (2002), from 1995 to 1999 Canada was the second largest exporter of virtual water. Being a water-rich country in both regards, Canada appears to be aiding the global water balance. However, water management at this scale does not consider possible environmental implications within the country (for example, at a watershed scale) of net water exportation. Moreover, Kumar and Singh (2005) concluded that there is no current correlation between water availability and amount of virtual water exported by a country.

Though first discussed as a global economic tool, virtual water has recently become an environmental consideration at regional scales, and is now referred to as all water consumed in the production of a commodity (Brown et al. 2009; Fang et al. 2010; Montesinos et al. 2011). Hoekstra and Chapagain (2008) further defined the VWC as the volume of water consumed per ton of good, measured at the location of production. Hoekstra and Chapagain (2007) proportioned overall global water consumption as follows: $86 \%$ agricultural, $9 \%$ industrial, and $5 \%$ domestic. Due to agriculture being the largest consumer, virtual water has mostly been studied within this sector. Globally, irrigation accounts for $65-70 \%$ of all water takings (Shiklomanov 2000), which produces $40 \%$ of food, from only $17 \%$ of all agricultural land (Abdullah 2006). Moreover, irrigation is responsible for $90 \%$ of global water consumption (Allan 1998). In areas of intense agriculture reliant on irrigation, virtual water becomes an influential factor in the local hydrologic cycle (Allan 2011; Schendel et al. 2007; Brown et al. 2009). 
To investigate agricultural water use at a regional scale, consumption sources must be further distinguished between blue and green water. Blue water is the liquid water above and below the surface, and green water is the soil moisture of the unsaturated zone consumed in evapotranspiration (Falkenmark and Rockstrom 2004). This concept is displayed in Fig. 1. Aldaya et al. (2009) then specified soil water from irrigation, either from ground or surface sources, to be classified as blue water, which proceeding studies have corroborated (Hanasaki et al. 2010; Hoekstra et al. 2012; Montesinos et al. 2011; Zoumides et al. 2013). Virtual water content includes both blue and green water, with blue water as the most 'manageable' component, leaving considerations of green water efficiency often overlooked (Aldaya et al. 2009; Falkenmark and Rockstrom 2004).

Initial quantification of virtual water was done for crops (Hoekstra and Hung 2002), and for livestock and livestock products (Chapagain and Hoekstra 2004) by calculating the global virtual water trade of products in volumes of water per year and country. Though useful for general, widespread comparisons, the distinction between blue and green water were not made and the blue water sources were not identified. Aldaya et al. (2009) estimated the proportions of blue and green water in the VWC of corn, soybean and wheat, exported from USA, Canada, Argentina and Australia. Green water of a crop was taken equal to the lower of either the effective rainfall or the crop water requirement, and blue water was equal to the irrigation water used. Green water content of global agriculture has also been approximated (Chapagain and Hoekstra 2004; Chapagain et al. 2006; De Fraiture et al. 2004; Rockström et al. 1999). Siebert and Döll (2010) estimated the blue and green VWCs of 26 crops globally. Values were calculated through modeled soil water balances, run under different irrigation scenarios. Hanasaki et al. (2010) further identified blue water sources as either renewable or nonrenewable and nonlocal. Each source's contributions were quantified through an enhanced version of a global hydrological model (Hanasaki et al. 2008). Siebert and Döll (2010), Hanasaki et al. (2010), and Hanasaki et al. (2008) found the green component of virtual water to be significantly higher than the blue, with the former two determining the global average of virtual water exported in crops to be more than $80 \%$ green water.

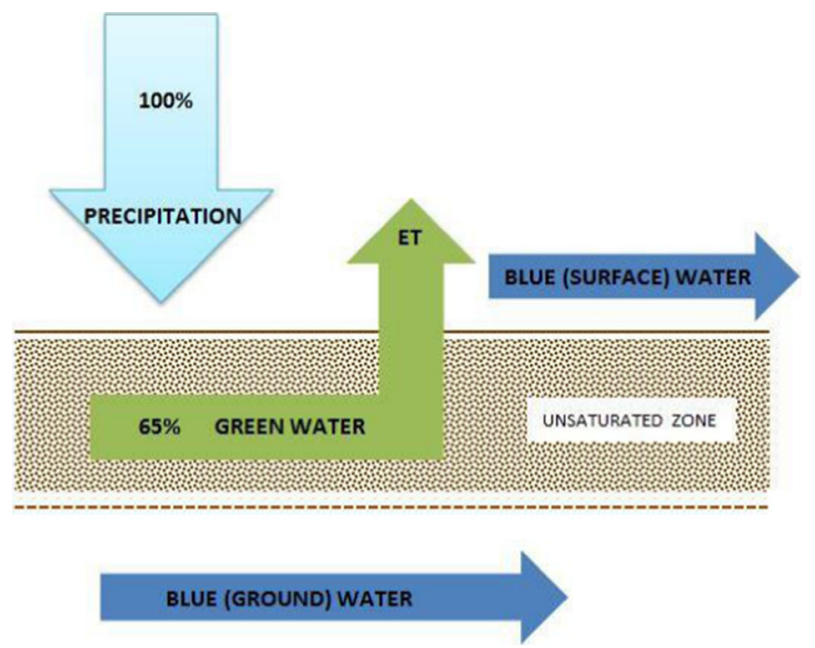

Fig. 1 Green and blue water as described by Falkenmark and Rockstrom (2004) 
Although previous research specifies virtual water's origin as green or blue, most studies are still conducted at a national scale, and do not differentiate between surface water and groundwater sources. Large countries that vary in climate will have different VWC for same commodity grown in different locations (Brown et al. 2009; Montesinos et al. 2011; Fang et al. 2010). For example, the VWC of apples for two watersheds in Canada was found to be $207 \mathrm{~m}^{3} / \mathrm{t}$ in the Lower Fraser Valley and $310 \mathrm{~m}^{3} / \mathrm{t}$ in the Okanagan Basin (Brown et al. 2009). Comparison to the country's average of $169 \mathrm{~m}^{3}$ / t, determined by Chapagain and Hoekstra (2004), displayed the ineffectiveness of applying national values to smaller scales (Brown et al. 2009). Ababaei and Eteladi (2014) also addressed this issue by calculating the water footprint of wheat production in Iran at a regional scale and then comparing the results to water footprints calculated at national and global scales. They showed that the water footprint of wheat in Iran determined by Chapagain and Hoekstra (2004) at a national scale is $54 \%$ greater than their regional scale estimate (Ababaei and Eteladi 2014). A study of virtual water flows at a watershed scale in the Guadalquivir River Basin of Spain calculated the blue virtual water components of crops and was useful to determine the most water efficient irrigated crops specific to the area, to enable farmers to make better informed decisions on planting and water productivity (Montesinos et al. 2011). Another study calculated virtual water flows between the political regions of China, and outlined the geographical pattern of green and blue water proportions in crops (Sun et al. 2013). Given that green water has a lower opportunity cost, it was recommended transferring grain from the green water-rich areas to the areas more dependent on blue water (Sun et al. 2013). An additional study in China calculated regional blue and green VWCs of seven crops in the Shiyang River basin to determine the proportional use of green water in each region and improve efficiency of blue water allocation ( $\mathrm{Su}$ et al. 2014).

Recently, because of increasing concerns of groundwater depletion, determining the specific source of blue water has become of interest. Siebert et al. (2010) created a global inventory of groundwater use in irrigation practices. Using the Global Map of Irrigation Areas along with the Global Crop Water Model (Siebert and Döll 2010), it was determined that globally $43 \%$ of total water consumed through irrigation is groundwater, with the leading consumer countries of India, China and the USA. Fang et al. (2010) studied virtual water in the Turpan Basin of China, and distinguished the surface water component through hydrological stations and annual river runoff, and the groundwater component through statistical data of groundwater extraction and additional exploration data. It was found that $58.22 \%$ of regional water consumption was supplied by groundwater, with the majority used in irrigation. Comparably, Zoumides et al. (2013) quantified overall groundwater and surface water use in agriculture throughout the Republic of Cyprus, but also did initial calculations of the blue and green water components. Using a soil water balance, which incorporated agrometereological data from 1995 to $2009,38 \%$ of average crop water use was blue water, with $81 \%$ of that from groundwater sources and $12 \%$ exceeding sustainable extraction rates. It was concluded the overexploitation was caused by type of crop (i.e., spring-summer) and inexpensive irrigation costs, not agricultural expansion (Zoumides et al. 2013). Wada et al. (2012) further distinguished the global proportion of groundwater used in irrigation that is supplied from nonrenewable sources. Using the hydrological model PCR-GLOBWB, along with soil maps and climate data from 1958 to 2001, Wada et al. (2012) determined that $20 \%$ of all irrigation water was sourced from nonrenewable groundwater (i.e., fossil groundwater, not active in the hydrologic cycle). 
As described in most virtual water studies performed at a regional scale, results can be used for decision-making relating to agricultural water conservation. However, the concept of virtual water has not been included in the current understanding of the hydrologic cycle (Schendel et al. 2007). Per the definition, VWC of a commodity is consumptive, and therefore, would be considered an unreturned withdrawal from a watershed. The benefits of calculating VWC at a watershed scale include increased precision of input data, application to specific commodities, and detailed information for land-use choices (Schendel et al. 2007). To date, there are no known studies on the VWC of agricultural commodities at a regional scale in Ontario, Canada, and very few regional studies globally, although growing (e.g., Su et al. 2014). Recently, integrated water budgets for watersheds in Ontario have been initiated by regional conservation authorities due to concerns of increasing water stresses caused by growing populations (AquaResource 2009a). Within these water budgets, agricultural water consumption is accounted for by applying a generic consumptive factor of 0.75 to water use estimates. This assumes that $75 \%$ of water withdrawal for agricultural use is consumed and $25 \%$ is returned to the hydrologic cycle. Agricultural water use estimates come from the provincial Ontario Ministry of Environment's Permits To Take Water (PTTW) Database, which outlines the maximum water withdrawals permitted for various uses including an individual farm. However, this accounting and reporting system does not include water takings below 50,000 L/day or those used for livestock watering. These are often estimated from community interviews (e.g., Wong 2011).

Incorporating virtual water into a water budget, rather than using general consumptive factors, can provide crop-specific consumption rates, identification of blue and green water use, and distinction of virtual blue water sources. With this data, a more precise understanding of high water consumers is available, as well as identification of direct contributors to groundwater depletion. This information can aid in strategic planning of future agriculture in terms of encouraging increased production of water-efficient crops and importation of regionally water-intensive crops. Moreover, calculations of the VWC can demonstrate the effectiveness and weakness of the current method for determining agricultural water consumption in water budgets, which is based on streamflow models and water-use estimates, and do not include crop-specific data (AquaResource 2009a).

This research is one of the first studies to apply the virtual water concept to a subwatershed scale, while identifying the green and blue water contents as well as the groundwater proportion of blue water. This study emphasizes the value of virtual water calculations at a small scale and identifies where the current methods can be improved. The objectives are: 1) to determine the VWC of crops in a subwatershed for the years 1983, 2011 and 2012 (i.e., when detailed crop inventory is available for the study area); 2) to quantify the proportion that is groundwater; and 3) to determine how the virtual water method compares to the traditional water budget approach for calculating agricultural water consumption. Though the results are site-specific, the method, with adjustments for differences in regional practices, can be applied to any watershed and is anticipated to be specifically useful for arid to semi-arid areas with intense irrigation reliant on groundwater sources. By using real climate data and crop inventory, this virtual water method gives a more accurate calculation of agricultural water consumption than typical water budgeting methods, which primarily use consumptive factors and numerical model calibrations to determine consumption. In this way, water management can be informed through a better understanding of the local human-influenced hydrologic cycle and the identification of the high water consumers in an agricultural context. Distinguishing methods which improve the accuracy of a water budget are ever pertinent as water availability and protection grow in global importance. 


\section{Methods}

\subsection{Study Area}

The Whitemans Creek study area is a subwatershed of the Grand River, located in southern Ontario, Canada, approximately $100 \mathrm{~km}$ west of Toronto (Fig. 2). Within the Grand River watershed, the Whitemans drainage basin has the highest agricultural water-use and lowest municipal water demand (AquaResource 2009a). Irrigation water is withdrawn using wells, through dug ponds, and also directly pumped from the Creek (Kovacs 2014). Of the 130 Permits to Take Water (PTTW) distributed in 2010, 127 were for the agricultural sector, 2 were industrial and 1 was for the municipality of Bright (Wong 2011). PTTW are required in Ontario for withdrawals greater than 50,000 L per day. Water use in Bright services a population of 409 residents, and is sourced from groundwater (Wong 2011). In 2012, $74 \%$ of the entire $398 \mathrm{~km}^{2}$ subwatershed was occupied by active agriculture, with $30 \%$ of the land area having corn crops. The Whitemans Creek subwatershed has been identified as being water-stressed, specifically classified as "Moderate potential for stress under Drought Conditions" during a Tier 2 water budget study for the supply wells in the village of Bright (AquaResource 2009b). A Tier 3 Water Quantity Risk Assessment is being conducted for the area (GRCA, personal communication).

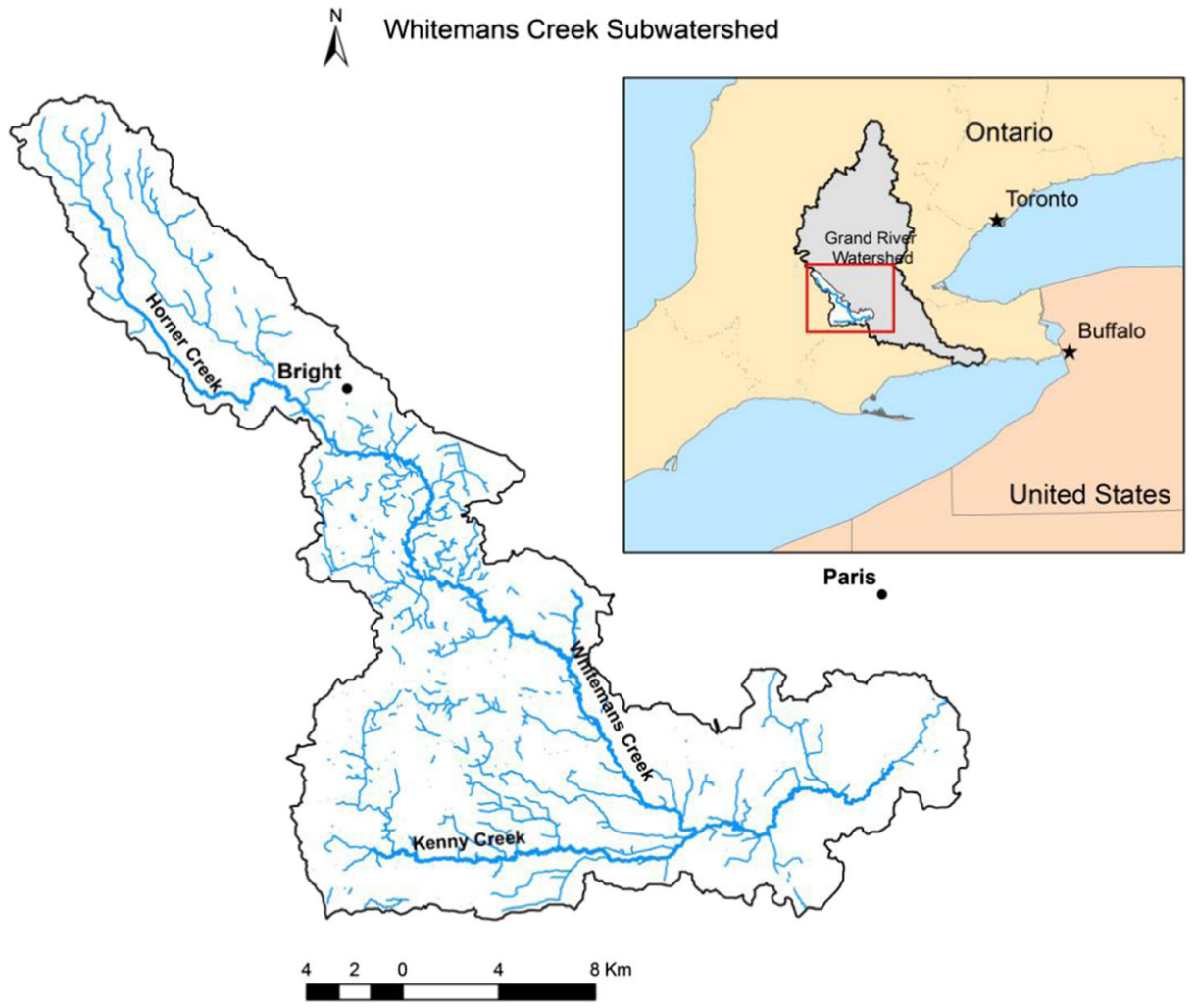

Fig. 2 The study location of the Whitemans Creek subwatershed, within the Grand River watershed in Ontario, Canada, with rivers and streams illustrated 
Southern Ontario is an active area of agricultural productivity attributed to its humid continental climate (Brown et al. 1980). Regions near the Great Lakes experience a lake effect where temperature extremes are moderated, often prolonging the growing season in the fall. The precipitation totals from April to September were $602 \mathrm{~mm}$ for 1983, $597 \mathrm{~mm}$ for 2011 and $375 \mathrm{~mm}$ for 2012. The values for 1983 and 2011 are comparable with the historic average that ranges between 400 and $600 \mathrm{~mm}$ (Colombo et al. 2007); however, 2012 was, in a comparison, a dry growing season.

The local soil of the Whitemans Creek watershed consists of sand and gravel in the south, and clay and silty tills in the north. The terrain is mostly low relief ranging from 360 to 254 masl, with the northern area partially encompassing the Waterloo Moraine complex. This complex is host to various overburden aquifers and can have a thickness up to $120 \mathrm{~m}$ (AquaResource 2009a). The southern portion of the basin overlies the Norfolk Sand plain which contains a shallow, unconfined and permeable sand aquifer. The surface of the water table ranges from approximately 325 masl in the north and 250 masl in the south (AquaResource 2009a). These local groundwater sources not only help feed the subwatershed's tributaries and the Bright residents, but are also a significant contributor to irrigation (Wong 2011). The flows within Whitemans Creek itself are also highly dependent on groundwater inputs. Groundwater supports the cold water fishery in the Creek (Wong 2011). Low water issues in the Creek have been identified for many years, and the GRCA Low Water Response team has subsequently been working with the irrigators on this issue (Kovacs 2014; Wong 2011).

The primary crops in the subwatershed include corn (maize), soybeans and winter wheat (AAFC 2013b). Tobacco was previously a commonly grown crop in the area, but has since declined because of the decreasing market demand. Other frequently grown crops include alfalfa, various fruits, market vegetables, and canola (total areas for each are listed in Table 3). Due to the high production of cash crops and low human population, it is assumed that all agricultural commodities are exported out of the subwatershed with negligible imports. Consequently, within the local water budget, all VW of crops would be considered a hydrologic output.

\subsection{Process}

The original method of determining the crop-specific virtual water requirement (VWR) is presented by Hoekstra and Hung (2002). It is based on crop evapotranspiration calculations outlined in the Food and Agriculture Organization (FAO) Paper 56 (Allen et al. 1998). However, this method is limiting in three ways: 1) it assumes all crops are grown to their optimal potential with irrigation applied where needed; 2) it does not differentiate between green and blue water components; and 3) it uses the single crop coefficient as an averaged approximation of the dual crop coefficient. The latter crop coefficient differs from the former in that it analyses plant transpiration and bare soil evaporation separately. The method presented herein, as shown in Fig. 3, also uses Paper 56 (Allen et al.1998) but attempts to resolve the previous limitations, and to further specify the sources of blue water (that is, groundwater or surface water).

This approach considers and includes irrigation scheduling (e.g., determined from interviews with local farmers by Wong (2011) for this study area), the difference in crops that were solely rain-fed and those which were irrigated, and the sources of water abstraction for irrigation. Within the Whitemans Creek subwatershed, there are only three crops that are irrigated: fruits (e.g., apples), field vegetables (e.g., tomatoes and lettuce) and tobacco. 


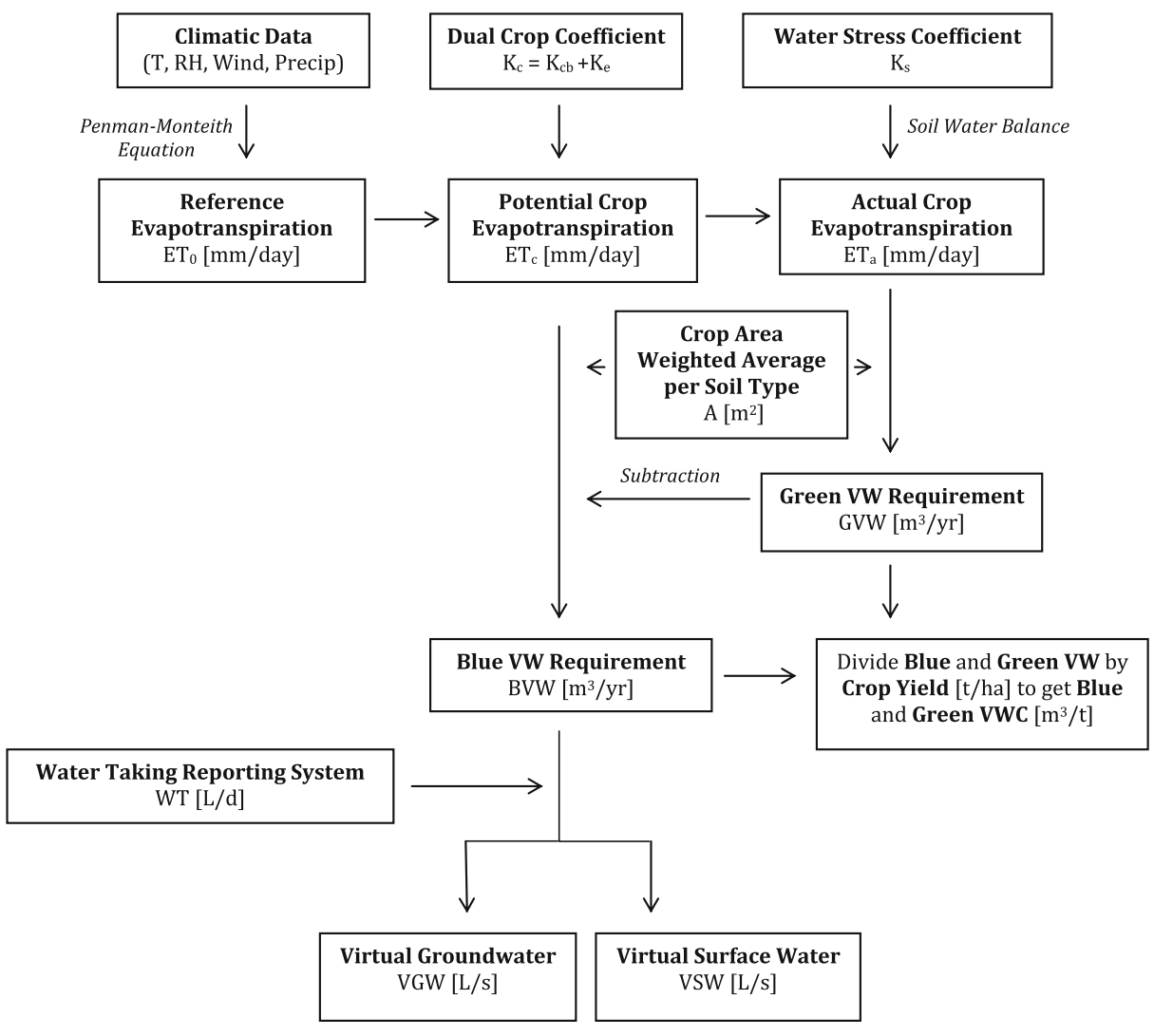

Fig. 3 Process diagram of crop-specific VW calculations, where T is temperature, RH is relative humidity, and precip is precipitation

Typically in the Grand River watershed, irrigation application is limited to the dates of June 20 to September 10 (Wong 2011).

To calculate VW, the reference crop evapotranspiration $\left(\mathrm{mm} \mathrm{yr}^{-1}\right)$ is first calculated using the FAO Penman-Monteith equation, as outlined by Allen et al. (1998):

$$
E T_{0}=\frac{0.408 \Delta(R n-G)+\frac{\gamma 900}{T+273} U_{2}\left(e_{s}-e_{a}\right)}{\Delta+\gamma\left(1+0.34 U_{2}\right)}
$$

where $\mathrm{ET}_{0}$ is the reference crop evapotranspiration, $\Delta$ is the slope of the vapour pressure curve $\left(\mathrm{kPa}^{\circ} \mathrm{C}^{-1}\right), \mathrm{Rn}$ is the net radiation at the crop surface $\left(\mathrm{MJ} \mathrm{m} \mathrm{m}^{-2} \mathrm{~d}^{-1}\right), \mathrm{G}$ is the soil heat flux density $\left(\mathrm{MJ} \mathrm{m}{ }^{-2} \mathrm{~d}^{-1}\right), \gamma$ is the psychrometric constant $\left(\mathrm{kPa}^{\circ} \mathrm{C}^{-1}\right), \mathrm{T}$ is the air temperature at $2 \mathrm{~m}$ height $\left({ }^{\circ} \mathrm{C}\right), \mathrm{U}_{2}$ is the wind speed at $2 \mathrm{~m}$ height $\left(\mathrm{m} \mathrm{s}^{-1}\right), \mathrm{e}_{\mathrm{s}}$ is the saturation vapour pressure $(\mathrm{kPa})$, and $\mathrm{e}_{\mathrm{a}}$ is the actual vapour pressure $(\mathrm{kPa})$. This is used to calculate the potential crop evapotranspiration $\left(\mathrm{m}^{3} \mathrm{yr}^{-1}\right)$ in the following equation:

$$
E T_{c}=0.001 \times A \times\left(K_{c b}+K_{e}\right) \times E T_{0}
$$

where $\mathrm{ET}_{\mathrm{c} .}$ is the potential crop evapotranspiration, 0.001 is a unit conversion factor, $\mathrm{A}$ is the crop area $\left(\mathrm{m}^{2}\right), \mathrm{K}_{\mathrm{cb}}$ is the basal crop coefficient which accounts for transpiration, and $\mathrm{K}_{\mathrm{e}}$ is the 
soil evaporation coefficient. The basal crop coefficient is taken from values derived by Allen et al. (1998) for each crop in a subhumid climate. To account for climatic conditions varying from subhumid, daily $\mathrm{K}_{\mathrm{cb}}$ values are adjusted if the minimum relative humidity $\left(\mathrm{RH}_{\mathrm{min}}\right)$ is different from $45 \%$ or $\mathrm{U}_{2}$ is different from $2 \mathrm{~m} \mathrm{~s}^{-1}$, using the following equation:

$$
K_{c b}=K_{c b(\text { Given })}+\left[0.04\left(U_{2}-2\right)-0.004\left(R H_{\min }-45\right)\right]\left(\frac{h}{3}\right)^{0.3}
$$

where $\mathrm{K}_{\mathrm{cb}(\text { Given })}$ is the initial $\mathrm{K}_{\mathrm{cb}}$ value outlined by Allen et al. (1998) and $\mathrm{h}$ is the mean plant height $(\mathrm{m})$. The soil evaporation coefficient $\left(\mathrm{K}_{\mathrm{e}}\right)$, as defined by Allen et al. (1998), accounts for the evaporation component of $\mathrm{ET}_{\mathrm{c}}$, and is bounded by an upper and lower limit. Its maximum value, equal to the maximum crop coefficient $\left(\mathrm{K}_{\mathrm{c} \max }\right.$, where $\left.\mathrm{K}_{\mathrm{c}}=\mathrm{K}_{\mathrm{cb}}+\mathrm{K}_{\mathrm{e}}\right)$ and occurring after irrigation or rainfall, is limited by available energy for evaporation at the soil surface. The coefficient's lower limit, zero, occurs when the soil surface has dried and the soil water content is equal to half the content at wilting point. The calculation of $\mathrm{K}_{\mathrm{e}}$ is:

$$
K_{e}=K_{r}\left(K_{c \max }-K_{c b}\right) \leq f_{e w} K_{c \max }
$$

where $\mathrm{K}_{\mathrm{r}}$ is a dimensionless evaporation reduction coefficient determined from the cumulative evaporation depth, the calculation process of which is shown in Paper 56 (Allen et al. 1998), and $f_{e w}$ is the fraction of the soil surface that is exposed and experiences most of the evaporation. Suggested values for each crop's $f_{\text {ew }}$ at different growing stages are found in Paper 56 (Allen et al. 1998).

To obtain the actual crop evapotranspiration $\left(\mathrm{m}^{3} \mathrm{yr}^{-1}\right)$ from $\mathrm{ET}_{\mathrm{c}}$, a water stress coefficient $\left(\mathrm{K}_{\mathrm{s}}\right)$, varying from 0 to 1 , is applied. This coefficient accounts for conditions when the soil water content cannot fulfill the potential crop evapotranspiration, and is specifically important for rain-fed crops. It is calculated using the following equation, as provided by Allen et al. (1998):

$$
K_{s}=\frac{T A W-D_{r}}{(1-p) T A W}
$$

where TAW is the total available soil water in the root zone $(\mathrm{mm}), \mathrm{D}_{\mathrm{r}}$ is root zone depletion, and $\mathrm{p}$ is the fraction of TAW that can be taken up by a crop's roots without experiencing water stress. Both TAW and $\mathrm{D}_{\mathrm{r}}$ are calculated following methods given by Allen et al. (1998) and are dependent on soil conditions and crop root depth. Values of $\mathrm{p}$ are found in Paper 56 by Allen et al. (1998). Using $\mathrm{K}_{\mathrm{s}}$, the daily $\mathrm{ET}_{\mathrm{a}}$ is calculated as follows:

$$
E T_{a}=K_{s} \times E T_{c}
$$

The $\mathrm{ET}_{\mathrm{a}}\left(\mathrm{m}^{3} \mathrm{yr}^{-1}\right)$ quantifies the green virtual water requirement (VWR) of crops and is supplied by precipitation. Crops which are also irrigated have a blue VWR during the irrigation schedule (e.g., June 20 - September 10 for the Whitemans Creek study area). This is calculated as the difference between $\mathrm{ET}_{\mathrm{c}}$ and $\mathrm{ET}_{\mathrm{a}}$, and assumes irrigation fulfills the crop's potential water consumption. Using water-taking reporting data, the blue VWR is further distinguished as ground or surface water. For the present study, this is done for the years of 2011 and 2012 as the data is not available for 1983. In 2011 and 2012, 77 and $81 \%$ of the active water taking permits reported the actual water quantity use and water sources, respectively. Because not all permit holders reported their use, a weighted ratio of ground to surface water withdrawn is 
calculated with the available data and then applied to the total VWR of each year. Blue and green VWCs $\left(\mathrm{m}^{3} \mathrm{t}^{-1}\right)$ are also calculated by:

$$
V W C=\frac{V W R}{Y \times A}
$$

where $\mathrm{Y}$ is the annual crop yield $\left(\mathrm{t} \mathrm{ha}^{-1}\right)$ and $\mathrm{A}$ is the crop area (ha).

\subsection{Data Sources}

Previous research has investigated VW flows at a national scale and acquired climate data from the FAO CLIMWAT database, which is used in conjunction with the computer program CROPWAT (Hoekstra and Hung 2002). This program provides values for seven meteorological parameters as long-term monthly means, and is based on agroclimatic data from over 5,000 stations globally (FAO2013). Although CLIMWAT is useful for analysis at the national and international scale, access to local, daily or hourly data is optimal for watershed scale investigations. Moreover, the program's most recent data is for 2000. For the calculation of reference evapotranspiration, data was collected from the Hamilton, Ontario Airport weather station, provided by the Historical Climate Data archive (Environment Canada 1983, 2011, 2012). Temperature corrections for the airport weather station being a non-reference station were applied based on differences between daily minimum and dew point temperatures (Allen et al. 1998).

Agricultural inventory data was collected from the Ontario Ministry of Agriculture and Food for 1983 (OMAF 2013), and from Agriculture and Agri-Food Canada 2011 and 2012 (AAFC 2013a, 2013b). This research was limited to these 3 years because this is the only comprehensive and detailed crop data currently available for the region. Crop inventory data was collected by OMAF through field surveying, and by AAFC through remote sensing. Annual crop yields were collected from OMAF Statistics for all 3 years investigated (Kulasekera 2013). Soil characteristics were determined using the Soil Survey Complex compiled by OMAF, AAFC and the Ontario Ministry of Natural Resources (MNR), as a geo-spatial database (OMAF 2003). Crop characteristics, such as root depth and crop height, were primarily taken from literature values and FAO Paper 56, with confirmation through interviews with Ontarian farmers where possible. Actual water use was recorded through the Water Taking Reporting System (WTRS) and compiled by the Ontario Ministry of the Environment for the years 2008 to present (MOE 2013). Water use data was given as daily uses for each month and were summed for the annual growing season (April to September).

\section{Results and Discussion}

\subsection{Virtual Water Requirements for the Overall Subwatershed}

The total calculated crop water consumption for the subwatershed is shown in Table 1 for the years of interest. The green and blue VW components are identified, as well as the blue water sources for 2011 and 2012 (the years when reported water takings are available). Overall the green water-use is much higher than blue water-use, which is expected for areas with a humid continental climate, such as southern Ontario, which require less extensive irrigation. However, as blue water is the manageable component of VW, its use and sources should be identified. For both 2011 and 2012, over $80 \%$ of the blue VW was sourced from groundwater, 
Table 1 Average annual crop water requirement for the Whitemans Creek subwatershed

\begin{tabular}{|c|c|c|c|c|c|}
\hline \multirow[t]{3}{*}{ Year } & \multicolumn{5}{|c|}{ Crop Water Requirement-Annual Average (L/s) } \\
\hline & \multirow[t]{2}{*}{ Total } & \multirow[t]{2}{*}{ Green VW } & \multicolumn{3}{|c|}{ Blue VW } \\
\hline & & & Ground & Surface & Total \\
\hline 2012 & 2,488 & 2,290 & 164 & 34 & 198 \\
\hline 2011 & 3,697 & 3,540 & 134 & 23 & 157 \\
\hline 1983 & 4,133 & 3,755 & - & - & 378 \\
\hline
\end{tabular}

with blue water-use increasing by $26 \%$ from 2011 to 2012 , likely due to the significant difference in precipitation (597 mm vs. $375 \mathrm{~mm}$ from 2011 to 2012).

The results in Table 1 are presented in L/s to be comparable to the agricultural water consumption estimated in the 2008 Grand River Integrated Water Budget (AquaResource 2009a). Blue VWR for 2011 was calculated to be $157 \mathrm{~L} / \mathrm{s}, 6 \mathrm{~L} / \mathrm{s}$ less than the agricultural water consumption of $151 \mathrm{~L} / \mathrm{s}$ which was calculated for the Whitemans Creek area in 2008 (AquaResource 2009a). This result helps to confirm the method presented in this study because agricultural water consumption, as labeled in the water budget, refers to the irrigation water-use and does not incorporate green water consumption by crops. Table 2 also shows the actual water-takings according to the WTRS. The water-use totals from reportings in 2011 and 2012 are lower than the calculated values of blue VW, as well as the water budget's consumption estimate. This discrepancy can be explained by two factors. Firstly, as shown in Table 2, not all those with water permits are recording or reporting their actual use. Secondly, as mandated by the MOE, those taking less than 50,000 L/d do not require a permit and are not required to record their takings.

Although it is reasonable that the 2011 blue VWR result is similar to the 2008 agricultural water consumption presented in the regional water budget, the results of this study are preferable for an understanding of agricultural land use impacts because, unlike the water budget analysis, crop-specific data is incorporated herein. The water budget by AquaResource (2009a) used maximum permitted pumping rates, taken from agricultural water permit data compiled in the PTTW database by the MOE. From comparisons with 135 available records of actual pumping rates, AquaResource (2009a) determined the average actual pumping rate, which was approximately $60 \%$ of the maximum permitted rate. A consumptive factor of 0.75 , representing a "good" irrigation system, was then assumed for the water budget based on a study that investigated different irrigation efficiencies. It was applied to the actual pumping rate to get a rate of agricultural water consumption. By calculating irrigation on a crop-specific basis, which is done for the present study, agricultural water consumption is identified at a

Table 2 Actual water takings from the WTRS, and the agricultural water consumption estimate for 2008 from the Grand River Watershed Integrated Water Budget (AquaResource 2009a)

\begin{tabular}{llllll}
\hline & & & \multicolumn{2}{l}{ Agricultural Water Takings (L/s) } \\
\cline { 5 - 6 } & Active Permits & \% Reporting & Groundwater & Surface Water & Total \\
\hline 2012 & 115 & 81 & 59 & 10 & 69 \\
2011 & 94 & 77 & 37 & 8 & 45 \\
GRCA Water Budget & - & - & - & - & 151 \\
\hline
\end{tabular}


smaller scale without using a generalized consumptive factor. The results are aggregated to provide a more reliable overall consumption rate for the study area. Furthermore, this method identifies green water component through calculation of crop evapotranspiration, which as shown in Table 3, represents a significant portion of the water budget.

The distribution of annual VWR throughout Whitemans Creek subwatershed is displayed in Fig. 4 for 2011 using the dominant crop for each agricultural field. The grey zones, covering approximately $26 \%$ of Whitemans Creek subwatershed, indicate locations where VWR was not quantified: urbanized areas, water bodies, forests, and agricultural fields that have been idle for 5 years or more. The fields requiring the highest VW amounts of 7,500 $\mathrm{m}^{3} /$ ha (for orchards) occupy some of the smallest areas within the subwatershed. The second largest consumer at approximately $5,000 \mathrm{~m}^{3} /$ ha, occupies a significant portion, specifically in the northern region where there is a high density of corn fields.

\subsection{Crop-Specific Virtual Water}

The VWC of each crop investigated for the 3 years of interest are presented as their blue and green water components in Table 3 along with the area of land they occupied each year and their annual yield. Crops with a blue VWC greater than 0 (i.e., fruits, vegetables, and tobacco) are irrigated. The crop types for each year differed and depended on the agricultural data provided (AAFC 2013a, 2013b; OMAF 1983), leading to some missing data points for beans and canola. Tobacco has the highest blue VWC in each year $\left(676\right.$ to $\left.1,180 \mathrm{~m}^{3} / \mathrm{t}\right)$ with some of the lowest annual yields (2.9 to $3.0 \mathrm{t} / \mathrm{ha}$ ), implying it is the most inefficient user of irrigation water (that is, per ton yield) within the subwatershed. The increase in values over the 3 years is likely due to differences in climatic parameters since the tobacco yield has remained relatively constant at 3.0, 2.9 and 3.0 t/ha for 1983, 2011 and 2012, respectively. Alfalfa is one of the highest users of green water (ranging from 803 to $969 \mathrm{~m}^{3} / \mathrm{t}$ ). This is likely due to its deep root system and low annual yields (Kulasekera 2013). To identify annual changes in blue versus green VW consumption, the irrigated crops are specifically investigated. Table 3 shows that in 1983, all irrigated crops (fruits vegetables and tobacco) consumed more green water than blue water, whereas in 2011 and 2012, their blue water consumptions were all greater than those of green water. This decrease in green VWC with an increase in blue VWC may be explained by

Table 3 Crop-specific green and blue virtual water contents, crop area, and yield for 1983, 2011 and 2012

\begin{tabular}{|c|c|c|c|c|c|c|c|c|c|c|c|c|}
\hline \multicolumn{7}{|c|}{ Virtual Water Content $\left(\mathrm{m}^{3} / \mathrm{t}\right)$} & \multicolumn{3}{|c|}{ Crop Area $\left(\mathrm{km}^{2}\right)$} & \multicolumn{3}{|c|}{ Yield (t/ha) } \\
\hline & \multicolumn{2}{|l|}{1983} & \multicolumn{2}{|l|}{2011} & \multicolumn{2}{|l|}{2012} & \multirow[t]{2}{*}{1983} & \multirow[t]{2}{*}{2011} & \multirow[t]{2}{*}{2012} & \multirow[t]{2}{*}{1983} & \multirow[t]{2}{*}{2011} & \multirow[t]{2}{*}{2012} \\
\hline & Green & Blue & Green & Blue & Green & Blue & & & & & & \\
\hline Alfalfa & 817 & 0 & 803 & 0 & 969 & 0 & 8 & 59 & 39 & 6.5 & 5.6 & 4.6 \\
\hline Beans & - & - & 180 & 277 & 155 & 408 & - & 7 & 2 & - & 7.7 & 6.9 \\
\hline Canola & - & - & 1,034 & 0 & - & - & - & 0.5 & - & - & 2.1 & - \\
\hline Corn & 827 & 0 & 523 & 0 & 323 & 0 & 116 & 125 & 120 & 5.8 & 9.5 & 9.6 \\
\hline Grains/Cereals & 1,423 & 0 & 468 & 0 & 451 & 0 & 40 & 47 & 24 & 3.4 & 5.1 & 5.3 \\
\hline Fruits & 254 & 217 & 116 & 164 & 218 & 776 & 0.2 & 0.1 & 2 & 15.9 & 26.7 & 6.0 \\
\hline Soybeans & 1,749 & 0 & 579 & 0 & 364 & 0 & 62 & 54 & 87 & 2.0 & 3.0 & 3.1 \\
\hline Vegetables & 106 & 56 & 12 & 42 & 16 & 36 & 5 & 6 & 3 & 31.7 & 69.2 & 86.2 \\
\hline Tobacco & 943 & 676 & 496 & 1,158 & 381 & 1,180 & 54 & 4 & 10 & 3.0 & 2.9 & 3.0 \\
\hline
\end{tabular}




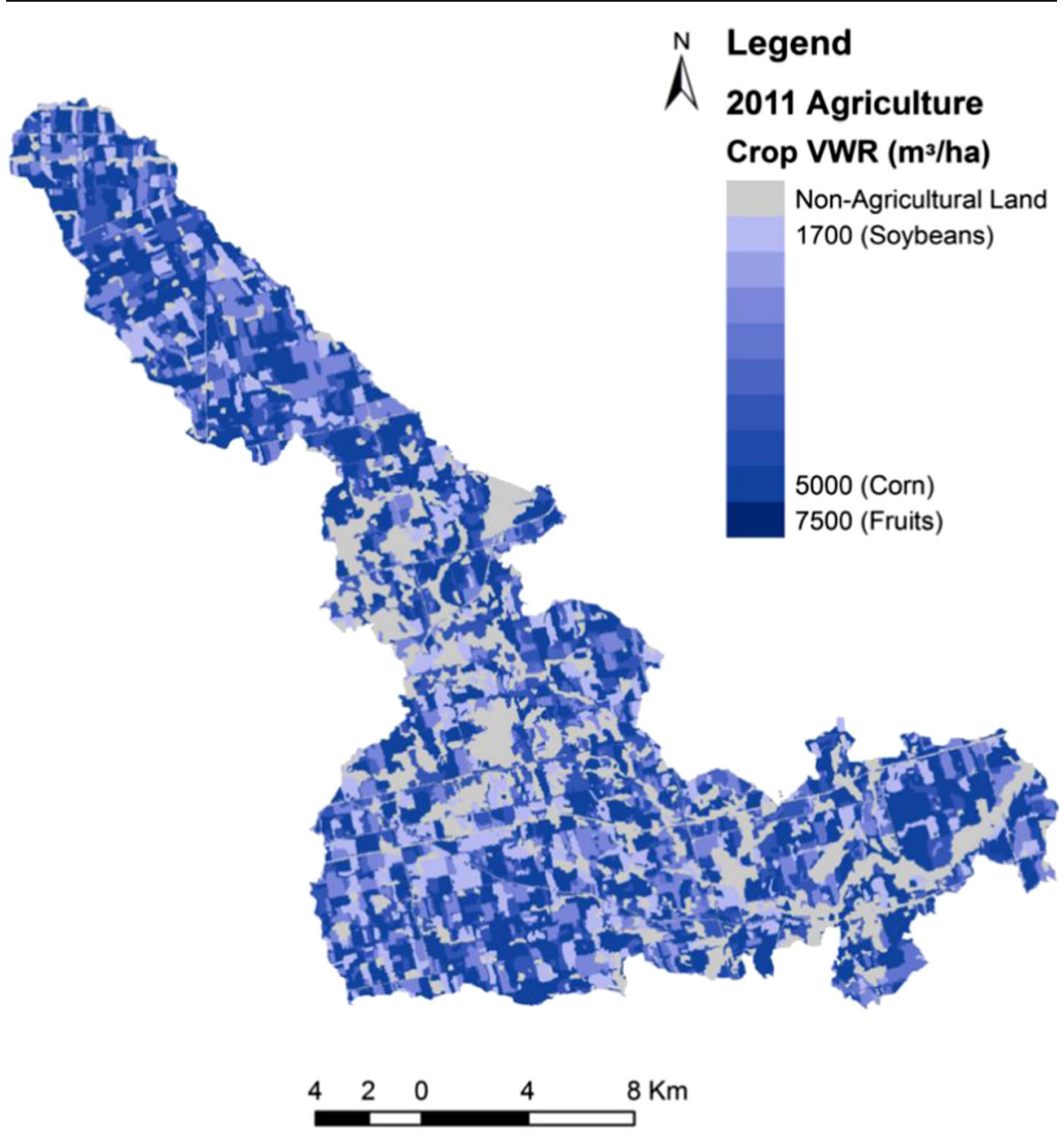

Fig. 4 Annual virtual water requirements throughout the Whitemans Creek subwatershed

advances in farming practices increasing water-use efficiency, while the relatively hotter and drier weather experienced in 2012 still required higher than average irrigation application.

The annual virtual water requirements for major water-consuming crops in Whitemans Creek are presented in Fig. 5 for all years investigated. Corn consistently has the highest VW requirements for all 3 years with relatively average annual yields ranging from 5.3 to 9.6 t/ha. The significant decrease in 2012 demonstrates the climate's effect on the water requirements of rain-fed crops when a growing season experiences low precipitation. The decrease in VW requirement for tobacco is likely due to the overall decline in the industry $\left(54 \mathrm{~km}^{2}\right.$ in 1983 to $10 \mathrm{~km}^{2}$ in 2012).

The crop-specific green and blue VW requirements for crops in 2011 are displayed in Fig. 6 on a per hectare basis. Fruits have the highest blue VW use of $4,387 \mathrm{~m}^{3} / \mathrm{ha}$. However, they only occupied $0.03 \%$ of the total agricultural land in 2011. Although the majority of crops are not irrigated, Fig. 6 shows that for those which are irrigated, $50 \%$ of the VW requirement is supplied by blue water. Soybeans were calculated to 


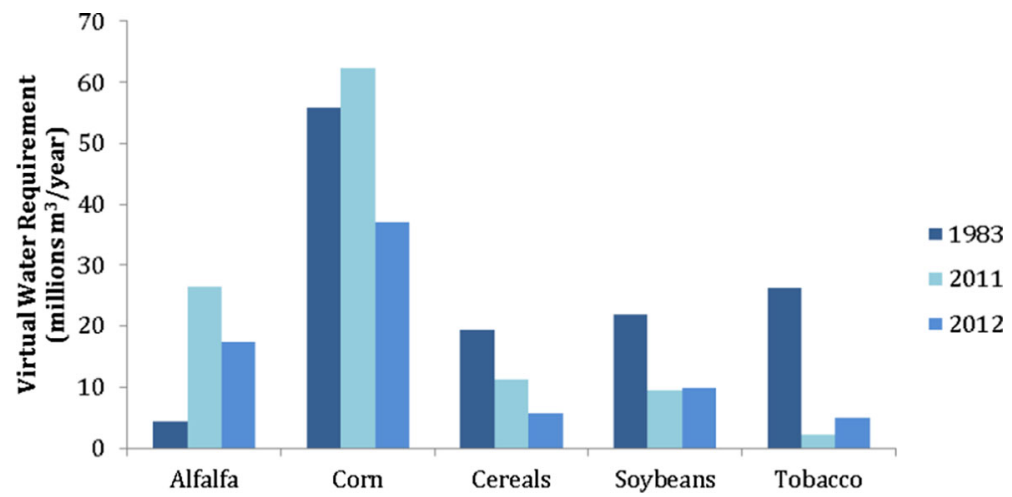

Fig. 5 Annual virtual water requirements of major water-consumers for 1983, 2011 and 2012

have the lowest VW requirement of $1,727 \mathrm{~m}^{3} /$ ha, which was solely supplied by green water. Conversely, corn and alfalfa are the highest users of green VW consuming 4,964 and $4,522 \mathrm{~m}^{3} / \mathrm{ha}$, respectively. This result is expected due to the crops' extensive root systems, and implies they create the greatest stresses on the local soil water budgets. The calculated VW requirement of corn is similar to the value found by Brown et al. (2009) in the Lower Fraser Valley (LFV) of British Columbia, Canada. Their study determined the VW requirement of corn to be just below $5,000 \mathrm{~m}^{3} / \mathrm{ha}$. The LVF basin was chosen as a representative wet Canadian watershed. Considering the humid climate of Whitemans Creek, it would be expected for the two values to be similar.

Quantitative information on crop use of soil moisture and blue water requirement is useful for land-use planning and water resources conservation efforts. If an area is identified as water-stressed, it would be beneficial to consider planting less waterintensive crops such as soybeans over high water-users such as corn. Furthermore, if

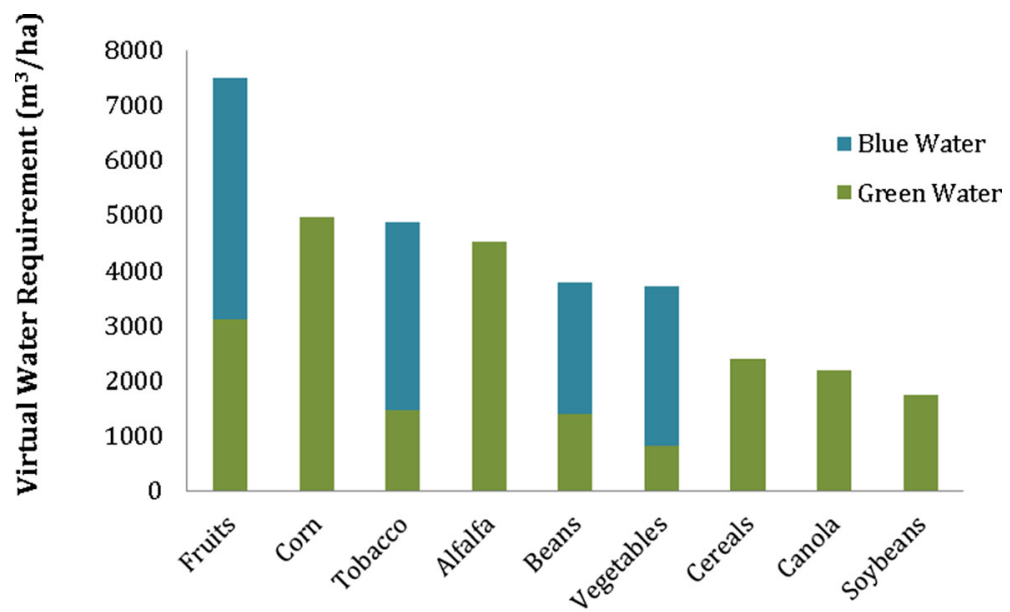

Fig. 6 Green and blue virtual water requirements per hectare of major crops for 2011 
groundwater levels or surface water sources are depleting, a management decision could be made to plant crops which do not require irrigation in contrast to those which do. Again, this crop-specific information is generally lacking from typical water budget analyses, such as described in AquaResource (2009a) for the present study area. The method presented herein identifies the green water component through calculation of crop evapotranspiration using the Penman-Monteith equation, whereas typical water budget analyses only determine overall evapotranspiration for an entire subwatershed. In addition, for the present study, it is determined using a continuous streamflow generation model known as the Guelph All-Weather Sequential Events Runoff (GAWSER) model, and is calculated by subtracting the average runoff and recharge from precipitation. This method is less intensive than the Penman-Monteith and is considered less accurate. It is recommended that methods to determine ET, such as Penman-Monteith, are used when detailed quantification of crop water use is desired.

Overall, blue VW contents of crops were greater in 2011 and 2012 than 1983, meaning a larger volume of irrigation water is required per ton of crop produced in these later years in the subwatershed. Considering that over $80 \%$ of this blue water is sourced from Whitemans Creek shallow aquifers, any increase in blue VW results in a greater amount of groundwater lost to the atmosphere or exported out of the subwatershed with the crops. Knowing crop-specific blue VW identifies areas where the greatest amounts of water are extracted and may require changes in farming or water management practices. This is especially critical when the completion of a Tier 3 Water Budget and Water Quantity Risk Assessment is required. Under Ontario's Clean Water Act, 2006, there are three tiers of water budgets and stress assessments (AquaResource 2011). Tiers 1 and 2 assess stresses to the hydrologic cycle within a watershed. Tier 3 further evaluates the risks to water quantity and the ability for a community's drinking demands to be met. Tier 3 assessment is conducted in locations that have specifically been assigned to have a moderate or significant water quantity stress level through Tier 2 assessments (AquaResource2011). With water quantity outlined as an issue for the agriculturally dominated Whitemans Creek subwatershed, it is important to present and analyze alternative, detailed methods to calculate crop water consumption.

The VW method presented herein improves upon the current water budget method when detailed crop water use information is required, because it analyses specific crop and climate data, and does not rely on crude consumptive factors or on numerical modeling to calibrate a value such as recharge or evapotranspiration. Furthermore, this method quantifies the green water component of crop water use, which is crucial in locations, like Ontario, where green water supplies the majority of agricultural water consumption. Confidence in results would improve with increased accuracy and amount of available data, for example, using local, reference weather stations and data collected from in-situ tests, such as specific crop parameters like root depth.

\section{Conclusions and Recommendations}

Investigating the true agricultural water consumption at a watershed scale is a difficult process that requires detailed, often hard to acquire parameters. Typical regional water budget calculations are based on water withdrawal estimates and numerical model simulation. With increasing demand on water quantity, methods to quantify water consumption in a detailed 
manner are pertinent. Using the cash-crop dominated subwatershed of the Whitemans Creek, virtual water calculations were conducted to determine water consumption at a regional scale on a detailed basis.

Using the method presented herein, total blue VW requirements (during the irrigation schedule of June 20 - September 10) were calculated as 378, 157 and $198 \mathrm{~L} / \mathrm{s}$ for 1983, 2011 and 2012, respectively. The 2011 value calculated in this study was similar to the estimated agricultural water consumption presented in the 2008 Grand River water budget, supporting the use of the VW method. It also identifies the current focus on irrigation wateruse, with less consideration of green water management. Further analysis of green VW, to identify high soil water-users, will be useful for land use planning and water resources management, especially since it is the major supply of crop water.

Evaluating the results over the 3 years investigated, it is apparent that blue water use per ton of crop is increasing. On a crop basis, this is suggested to be related to an increase in yield. On the basis of the entire subwatershed, this is likely caused by changes in climate. The hotter and drier weather seen in 2012 can only be an indicator of what is predicted to occur with climate change induced drought periods. Coupled with a growing population and resulting increased demand on the agricultural sector and water resources, blue water consumption is expected to grow. This is especially concerning in regions dominated by agriculture and heavily dependent on depleting groundwater sources. Groundwater is impacted by climate changes directly (e.g., recharge variations) and by land use changes induced by climate (e.g., more irrigation required), in addition to stressors like population growth (Taylor et al. 2013). With over $80 \%$ of blue water withdrawals being groundwater, and $98 \%$ of PTTW distributed to farmers, Whitemans Creek subwatershed is a relevant study area to demonstrate how the VW method can address the above stated issues. With local adjustments, such as determining a different irrigation schedule, this method can be extended to other agriculturally-dominated regions, and is predicted to be most pertinent for dry (arid) region growing crops that require much irrigation.

Future research should improve upon data collection capabilities. For this desktop study, many parameters were obtained from the literature, whereas local experimental values of plant parameters, such as growing schedules and root depths, would increase the accuracy of the results. In addition, the crop data provided by AAFC (2013a, 2013b) are based on satellite imagery and could again be improved through site-specific observations. Improvements in or more widespread data collected by remote sensing for crop identification will allow this method to be widely applied. To use the VW method in different climates and economies, variances in irrigation practices must also be considered. It is more realistic that crops are not irrigated to their full potential as this study assumes. In any situation, data from irrigation meters is ideal. Finally, 3 years of VW use were analyzed in this study due to the crop-specific data availability for 1981, 2011 and 2012. However, a region with more extensive data will allow for more years to be investigated leading to a better understanding of changing crop and climate trends.

When considering water management and water stress, it is important to understand how much water, blue or green, is consumed during the production of crops either through evapotranspiration or commodity exportation. This amount would be different if crops were not produced, and the land use was a natural forest, for example. If a watershed or subwatershed is the main supplier of crops for surrounding regions, theoretically, its water resources will eventually become depleted. This is a concern for groundwater resources when it is used as the major source for irrigation. This study is one of the first to present a method that calculates crop-specific green and blue VWC and includes further distinction of the blue VW into ground and surface water. The results help support the use of virtual water 
calculations at subwatershed scale and demonstrate the additional information they can provide over a typical water budget analysis that uses general crop consumptive factors. The virtual water concept is a useful tool to elucidate the impacts of various agricultural land uses on water stress and water budgets at a regional scale.

Acknowledgments The authors wish to acknowledge the Ontario Ministry of Food and Agriculture, specifically Ross Kelly and Stewart Sweeney, and the Grand River Conservation Authority, for their input and provision of data. Thank you to Gary Parkin, University of Guelph, for advisement on methods for this research.

\section{References}

AAFC (2013a) 2011 crop inventory Ontario [Raster]. Agriculture and Agri-Food Canada. Available: ftp://ftp.agr. gc.ca/pub/outgoing/aesb-eos-gg/Crop_Inventory/2011/Provinces/TIF/ [June 2013]

AAFC (2013b) 2012 crop inventory Ontario [Raster]. Agriculture and Agri-Food Canada. Available: ftp://ftp.agr. gc.ca/pub/outgoing/aesb-eosgg/Crop_Inventory/2012/Provinces/TIF/ [June 2013]

Ababaei B, Eteladi HR (2014) Estimation of water footprint components of Iran's wheat production: comparison of global and national scale estimates. Environ Process 1(3):193-205. doi:10.1007/s40710-014-0017-7

Abdullah KB (2006) Use of water and land for food security and environmental sustainability. Irrig Drain 55: 219-222

Aldaya MM, Allan JA, Hoekstra AY (2009) Strategic importance of green water in international crop trade. Ecol Econ 69(4):887-894

Allan JA (1996) Policy responses to the closure of water resources. In: Howsam P, Carter R (eds) Water Policy: Allocation and Management in Practice. Chapman and Hall, London

Allan JA (1997) Virtual water: a long term solution to water short Middle Eastern economies? SOAS occasional paper series, University of London

Allan JA (1998) Virtual water: a strategic resource. Ground Water 36(4):545-546

Allan T (2011) Virtural water tackling the threat to our planet's most precious resource. I.B Tauris \& Co. Ltd., New York

Allen RG, Pereira LS, Raes D, Smith M (1998) Crop evapotranspiration guidelines for computing crop water requirements. FAO Irrigation and Drainage Paper 56, Rome, Italy

AquaResource Inc. (2009a) Integrated water budget report: Grand River watershed. Grand River Conservation Authority. Available: http://www.sourcewater.ca/swp_watersheds_grand/Grand_2009WaterBudget_final.pdf [July 2013]

AquaResource Inc. (2009b) Tier 2 water quantity stress assessment report: Grand River watershed. Grand River Conservation Authority. Available: http://www.sourcewater.ca/swp_watersheds grand/Grand_2009Stress Final.pdf [July 2013]

AquaResource Inc. (2011) Water budget \& water quantity risk assessment guide: drinking source protection program. The Ontario Ministry of Natural Resources and the Ontario Ministry of Environment. Available: http://www.waterbudget.ca/waterbudgetguide [July 2013]

Brown DM, Mckay GA, Chapman LJ (1980) The climate of southern Ontario (3rd ed). Toronto ON: Supply and Services Canada

Brown S, Schreier H, Lavkulich LM (2009) Incorporating virtual water into water management: a British Columbia example. Water Resour Manag 23(13):2681-2696

Chapagain AK, Hoekstra AY (2004) Water footprints of nations. Value of Water Research Report Series No.16, UNESCO- IHE. Delft, The Netherlands

Chapagain AK, Hoekstra AY, Savenije HHG, Gautam R (2006) The water footprint of cotton consumption: an assessment of the impact of worldwide consumption of cotton products on the water resources in the cotton producing countries. Ecol Econ 60(1):186-203

Colombo SJ, McKenny DW, Lawrence KM, Gray PA (2007) Climate change projections for Ontario: practical information for policymakers and planners. Sault Ste. Marie, ON: Applied Research and Development Branch, Ontario Ministry of Natural Resources

De Fraiture C, Cai X, Amarasinghe U, Rosegrant M, Molden D (2004) Does international cereal trade save water? The impact of virtual water trade on global water use. International Water Management Institute, Colombo 
Earle A, Turton A (2003) 'The virtual water trade amongst countries of the SADC, Virtual water trade,' in A. Y. Hoekstra (ed.), Proceedings of the International Expert Meeting on Virtual Water Trade, Value of water research report series \# 12

Environment Canada (1983, 2011, 2012) Historical Climate Data. Government of Ontario. Available: http:// climate.weather.gc.ca/[June 2013]

Falkenmark M, Rockstrom J (2004) Balancing water for humans and nature. Earthscan, London

Fang S, Pei H, Liu Z, Beven K, Wei Z (2010) Water resources assessment and regional virtual water potential in the Turpan basin, China. Water Resour Manag 24(13):3321-3332

Gleeson T, Wada Y, Bierkens MFP, van Beek LPH (2012) Water balance of global aquifers revealed by groundwater footprint. Nature 488(7410):197-200

Hanasaki N, Kanae S, Oki T, Masuda K, Motoya K, Shirakawa N, Shen Y, Tanaka K (2008) An integrated model for the assessment of global water resources. Hydrol Earth Syst Sci 12:1027-1037

Hanasaki N, Inuzuka T, Kanae S, Oki T (2010) An estimation of global virtual water flow and sources of water withdrawal for major crops and livestock products using a global hydrological model. J Hydrol 384(3-4): 232-244

Hoekstra AY, Chapagain AK (2007) Water footprints of nations: water use by people as a function of their consumption pattern. Water Resour Manag 21(1):35-48

Hoekstra AY, Chapagain AK (2008) Globalization of water: sharing the planet's freshwater resources. Blackwell Publishing, Oxford

Hoekstra AY, Hung PQ (2002) Virtual water trade: a quantification of virtual water flows between nations in relation to international crop trade, value of water research report series, 12, UNESCOIHE, Delft

Hoekstra AY, Mekonnen MM, Chapagain AK, Mathews RE, Richter BD (2012) Global monthly water scarcity: blue water footprints versus blue water availability. PLoS One 7(2):1-e32688

Kovacs H (2014) The Whitemans Creek subwatershed drought contingency project: Water resource adaptation and management initiative. Grand River Conservation Authority

Kulasekera K (2013) Historical provincial estimates by crop, 1981-2013. [Online]. Ontario Ministry of Agriculture and Food. Available: http:/www.omafra.gov.on.ca/english/stats/crops/estimate hist metric.htm [July 2013]

Kumar MD, Singh OP (2005) Virtual water in global food and water policy making: Is there a need for rethinking? Water Resour Manag 19(6):759-789

Merrett S (2002) Water for agriculture: irrigation economics in international perspective. Routledge, London

MOE (2013) Water Taking Reporting System. [Computer file]. Ministry of Environment. Toronto: Freedom of Information and Privacy Office

Montesinos P, Camacho E, Campos B, Rodríguez-díaz JA (2011) Analysis of virtual irrigation water: application to water resources management in a Mediterranean river basin. Water Resour Manag 25(6):1635-1651

OMAF (2003) Soil survey complex [Vector]. Ontario Ministry of Food and Agriculture. Retrieved using Scholars GeoPortal

OMAF (2013) Agricultural Resource Inventory [Vector]. Ontario Ministry of Food and Agriculture. Retrieved using Scholars GeoPortal

Rockström J, Gordon L, Folke C, Falkenmark M, Engwall M (1999) Linkages among water vapor flows, food production and terrestrial ecosystem services. Conserv Ecol 3(2):1-5

Schendel EK, Macdonald JR, Schreier H, Lavkulich LM (2007) Virtual water: a framework for comparative regional resource assessment. J Environ Assess Policy Manag 9(3):341-355

Shah T, Roy AD, Qureshi AS, Wang J (2003) Sustaining Asia's groundwater boom: an overview of the issues and evidence. Nat Resour Forum 27(2):130-141

Shiklomanov IA (2000) Appraisal and assessment of world water resources. Water Int 25(1):11-32

Siebert S, Döll P (2010) Quantifying blue and green virtual water contents in global crop production as well as potential production losses without irrigation. J Hydrol 384:198-217

Siebert S, Burke J, Faures JM, Frenken K, Hoogeveen J, Döll P, Portmann FT (2010) Groundwater use for irrigation - a global inventory. Hydrol Earth Syst Sci 14(10):1863-1880

Singh OP, Sharma A, Singh R, Shah T (2004) Virtual water trade in dairy economy - irrigation water productivity in Gujarat. Econ Polit Wkly 39(31):3492-349

Su X, Li J, Singh V (2014) Optimal allocation of agricultural water resources based on virtual water subdivision in Shiyang River basin. Water Resour Manag. doi:10.1007/s11269-014-0611-5

Sun SK, Wu PT, Wang YB, Zhao XN (2013) The virtual water content of major grain crops and virtual water flows between regions in China. J Sci Food Agric 93:1427-1437

Taylor RG, Scanlon B, Döll P, Rodell M, van Beek R, Wada Y, Longuevergne L, Leblanc M, Famiglietti JS, Edmunds M, Konikow L, Green TR, Chen J, Taniguchi M, Bierkens MFP, MacDonald A, Fan Y, Maxwell 
RM, Yechieli Y, Gurdak J, Allen DM, Shamsudduha M, Hiscock K, Yeh PJF, Holman I, Treidel H (2013) Ground water and climate change. Nat Clim Change 3(4):322-329

Wada Y, van Beek LPH, Bierkens MFP (2012) Nonsustainable groundwater sustainingirrigation: A global assessment. Water Resour Res 48

Wichelns D (2001) The role of 'virtual water' in efforts to achieve food security and other national goals, with an example from Egypt. Agric Water Manag 49(2):131-151

Wong A (2011) Water Use Inventory Report for the Grand River Watershed. Grand River Conservation Authority. Available: http://www.grandriver.ca/Water/2011_GRCA_WaterUse.pdf [July 2013]

Zoumides C, Bruggeman A, Zachariadis T, Pashiardis S (2013) Quantifying the poorly known role of groundwater in agriculture: the case of Cyprus. Water Resour Manag 27(7):2501-2514 